\title{
Will protection of $17 \%$ of land by 2020 be enough to safeguard biodiversity and critical ecosystem services?
}

\author{
Frank W. Larsen, Will R. Turner and Russell A. Mittermeier
}

\begin{abstract}
To stem the loss of biodiversity and ensure continued provision of essential ecosystem services world leaders adopted the 20 Aichi Biodiversity Targets in 2010, to be fulfilled by 2020. One key target (Target 11) prescribes an expansion of the global protected area system to at least $17 \%$ of land surface and $10 \%$ of oceans by 2020 . Given that these targets are predominantly based on political feasibility rather than scientific evidence, it remains unclear whether fulfilment of Target 11 will suffice to safeguard biodiversity and ensure continued provision of essential ecosystem services. Despite many data gaps, in particular for ecosystem services, we can use existing global data to estimate the required protected area on land for biodiversity (a minimum of c. 17\%) and biomass carbon storage (a minimum of c. 7-14\% additional area to protect $75-90 \%$ of the unprotected carbon stock), which illustrates that the target of $17 \%$ of land will probably fall short in meeting these goals. As crossing thresholds or tipping points in ecosystems could trigger non-linear, abrupt change in delivery of ecosystem services, we need a science-driven understanding of how much protected, intact nature is needed to avoid unforeseen transgression of planetary boundaries.
\end{abstract}

Keywords Aichi targets, biodiversity, biodiversity conservation, carbon storage, $\mathrm{CBD}$, protected areas, protected area target, Target 11

\section{Introduction}

Tn 2002 world leaders committed through the UN Convention on Biological Diversity (CBD) 'to achieve by 2010 a significant reduction of the current rate of biodiversity loss' (CBD, 2012). This target was not met. The rate of biodiversity loss does not appear to be slowing: most indicators of the state of biodiversity (population trends and extinction risk, among others) continue to decline, with no significant recent reductions in rate, whereas indicators of

Frank W. LARSEN* (Corresponding author), Will R. TURnER and RusselL A. Mittermeier Conservation International, Arlington, Virginia, USA E-mail frankwugtlarsen@gmail.com

${ }^{*}$ Current address: European Environment Agency, Kongens Nytorv 6, 1050 Copenhagen K, Denmark.

Received 28 February 2013. Revision requested 29 April 2013.

Accepted 9 September 2013. First published online 12 May 2014. pressures on biodiversity (e.g. resource consumption, invasive alien species, climate change impacts) are increasing (Butchart et al., 2010; CBD, 2010a).

In October 2010 world leaders met in Nagoya, Japan, at the 1oth Conference of the Parties (COP10) of the CBD to negotiate a global deal to protect nature. They adopted a strategic plan for biodiversity and 20 targets (the Aichi Biodiversity Targets) for 2011-2020 that will constitute the framework for action until 2020 by all countries and stakeholders to save biodiversity and enhance its benefits for people (CBD, 2010b). A key recognition was that the current global network of protected areas, covering c. $12.9 \%$ of land surface (IUCN \& UNEP-WCMC, 2011) and only c. 1.17\% of the total ocean area (Toropova et al., 2010), falls short in protecting biodiversity and ecosystem services (the benefits that people derive from nature). Protected areas, ranging from reserves solely for the protection of nature to those that facilitate sustainable use of natural resources (Dudley, 2008), are widely recognized for their importance in conserving biodiversity and constitute an important cornerstone in halting biodiversity loss (Lovejoy, 2006). However, biodiversity is declining despite increased global coverage of protected areas. Many protected areas are not sufficiently managed, total area covered by protected areas is not yet sufficient to stem biodiversity loss, and the distribution of protected areas is such that many important areas for biodiversity remain unprotected (Butchart et al., 2012), including many areas in Biodiversity Hotspots (Myers et al., 2000), Key Biodiversity Areas (Eken et al., 2004), and especially Alliance for Zero Extinction sites (Ricketts et al., 2005). In Nagoya, countries settled on a target for the global coverage of protected areas that includes at least $17 \%$ of the terrestrial and inland water areas and $10 \%$ of the coastal and marine areas by 2020 (Target 11; CBD, 2010b). The previous vague target of 'decreasing the rate' of biodiversity loss by 2010 was replaced by a more specific target of 'preventing' extinction of known threatened species; i.e. Target 12 ('By 2020 the extinction of known threatened species has been prevented and their conservation status, particularly of those most in decline, has been improved and sustained'). Fulfilment of the global target for protected area on land would expand the current global coverage of protected areas by at least $4 \%$ by 2020, c. 5.9 million $\mathrm{km}^{2}$ (about twice the size of Argentina). The agreed target for the oceans represents almost a ten-fold increase over the 2010 level. However, the number and extent of marine protected areas has increased rapidly in recent years, with c. $2.3 \%$ currently 
protected (The Nature Conservancy, 2012). These targets are global and do not prescribe specific targets for individual countries, which will vary considerably among countries given that biodiversity and ecosystem services are not evenly distributed across the globe.

The ongoing loss of biodiversity is also eroding nature's ability to support human societies (TEEB, 2010). Humans depend on nature. The diversity of living organisms and ecosystems provides people with benefits such as fisheries, plant-derived medicines, climate regulation via carbon storage and sequestration, clean freshwater, protection from flooding and other natural disasters, adaptation to climate change, and pollination of crops, among others (Millennium Ecosystem Assessment, 2005). Ultimately, the global protected area network is the core of our efforts to preserve species and our collective natural capital, and the foundation of a global life support system that sustains us all. For example, nearly a third (33 out of 105) of the largest cities obtain a substantial portion of their drinking water directly from protected areas (Dudley \& Stolton, 2003). The benefits of protecting intact ecosystems with their multitude of ecosystem services frequently outweigh the costs of protecting them (Balmford et al., 2002; TEEB, 2010; Turner et al., 2012). The people for whom these benefits matter most are the world's poor, who depend disproportionately on nature for critical services such as clean water, for livelihoods, and for insurance against hard times, making conservation and development intertwined challenges (Sachs et al., 2009; TEEB, 2010; UNDP, 2011). For example, it has been estimated that ecosystem services and other nonmarketed natural goods account for $47-89 \%$ of the 'GDP of the poor' (i.e. the effective GDP or total sources of livelihoods of rural and forest-dwelling poor households) in some large developing countries (TEEB, 2010). The recent establishment of the Intergovernmental Platform on Biodiversity and Ecosystem Services, modelled after the influential Intergovernmental Panel on Climate Change, reflects increasing international recognition of these issues.

The global targets of protection of at least $17 \%$ of land and $10 \%$ of oceans by 2020 are predominantly set based on political feasibility. The question of how much nature needs to be protected to prevent biodiversity loss and ensure important ecosystem services is not well understood and answering it poses many challenges. Firstly, only $2.5 \%$ of known species have been assessed for their conservation status (Stuart et al., 2010) and only a small fraction of the estimated total number of species have been described by science (Mora et al., 2011). Secondly, there is still a poor understanding of a range of important issues such as the ecological underpinnings of ecosystem services (Kremen \& Ostfeld, 2005). Thirdly, we have limited understanding of tipping points in ecological systems and cannot yet predict the potential threshold effects of climate change and other anthropogenic pressures on biodiversity and ecosystem services (Barnosky et al., 2012). Recently, nine planetary boundaries within which it is expected that humanity can operate safely have been identified (Rockström et al., 2009a,b). Transgressing one or more of these planetary boundaries may be catastrophic because of the risk of crossing thresholds that will trigger non-linear, abrupt environmental change within continental- to planetaryscale systems. Rockström et al. (2009a,b) suggested that the boundary for biodiversity loss has already been transgressed, given the high rate of biodiversity loss.

The question of how much nature is needed is of critical importance. Despite multiple knowledge and data gaps we can use existing data to provide an approximate estimate of a minimum global target for protected area coverage on land for safeguarding biodiversity and ecosystem services (data for an equivalent marine analysis are currently unavailable). Such an estimate will necessarily be an approximation, and probably an underestimate given that data for most ecosystem services are lacking. But some estimate is needed to illustrate to what extent the current policy target for protected area coverage on land may be sufficient to meet its goals.

Here, we ask how much land is needed to protect biodiversity that is not already covered in the existing global protected area network. Unfortunately, reliable estimates of unprotected ecosystem services are difficult to derive given the scarcity of necessary global spatial data. However, global data are available for carbon storage and we therefore use this as an illustrative example to estimate a bare minimum extent of additional protected areas required to cover 75 and 90\% (arbitrarily chosen) of global biomass carbon in natural habitats. The carbon stored in natural habitats is of global importance for slowing climate change, and global deforestation and forest degradation account for c. $12 \%$ of global $\mathrm{CO}_{2}$ emissions annually (van der Werf et al., 2009). Curbing deforestation is seen as a cost-effective way of reducing $\mathrm{CO}_{2}$ emissions (McKinsey \& Company, 2009) and consequently an international financial mechanism to reduce emissions from deforestation and forest degradation (REDD+) has been adopted by the United Nations Framework Convention on Climate Change (UNFCCC, 2010). The protection of natural habitats is an effective way to ensure continued carbon storage, assuming effective management to prevent degradation (Scharlemann et al., 2010).

\section{Methods}

\section{Protected area coverage}

We used data on protected areas from the World Database on Protected Areas (WDPA; IUCN \& UNEP-WCMC, 2011). We included all national and international terrestrial 
protected areas except those listed as proposed or recommended. We did not include Indigenous and Community-Owned Conservation Areas as these are not formally protected, although they can provide many conservation benefits (Ricketts et al., 2010). Boundary data were available for 125,993 protected areas. For protected areas that lacked mapped boundary data but where the location and area were known, we calculated an approximate coverage by generating a circular buffer of the known area around the known point location $(n=17,366)$. Overlapping protected areas were dissolved to avoid double counting.

\section{Important sites for biodiversity conservation}

To answer the question of how much land is needed to protect biodiversity, we focused on globally critical sites for species and habitats (Eken et al., 2004; Langhammer et al., 2007). These areas have been identified at a national level by local stakeholders using a set of transparent and globally standardized criteria to ensure scientific soundness (Eken et al., 2004; Langhammer et al., 2007) and will thus be informative for a global estimate. Recent research shows that more than half of all these important sites for biodiversity remain unprotected (Butchart et al., 2012), and many are within Biodiversity Hotspots (Myers et al., 2000; Mittermeier et al., 2004, 2011). We can start from the amount of additional land needed to protect these unprotected critical sites for known biodiversity. The most advanced set of such important sites for biodiversity identified to date is that of Important Bird Areas (IBAs), with nearly 11,000 IBAs in c. 200 countries. We used polygon data for 10,403 IBAs (BirdLife International, 2011) with a total area of c. 9.4 million $\mathrm{km}^{2}$ ( $6.4 \%$ of global area), of which c. 4.4 million $\mathrm{km}^{2}$ (3.0\% of global area) is still unprotected according to data in the WDPA (we included partially and fully protected areas). However, IBAs have not been designated in some countries (including the biodiverse USA). The countries with polygons for IBAs constituted c. $90 \%$ of land (excluding Antarctica). Assuming unprotected IBAs occupy the same fraction in the few countries where IBAs are not yet designated, a fully defined global set of unprotected IBAs would comprise c. $3.3 \%$ of land $(3.0 \% \times 1 / 0.90=3.3 \%)$. We excluded the area of Antarctica to make this extrapolation conservative.

The identification of important sites for biodiversity for a broader suite of taxa (i.e. non-bird taxa) is incomplete. Identification of important sites for non-bird taxa (Key Biodiversity Areas, KBAs) has been completed in 12 countries to date, with many other countries in the process of finalizing/determining networks of priority sites (N. da Silva, pers. comm.). An analysis of the 12 countries with important sites for birds and for at least one non-bird taxon reveals that IBAs overall constitute $80 \%$ of the area of all known important sites for biodiversity. Based on the proportion of the area of important sites for birds to important sites for other taxa (McCarthy et al., 2012), we extrapolated the area of unprotected important sites for non-bird taxa.

\section{Carbon storage in protected areas}

We estimated the area that must be protected to limit carbon emissions resulting from land-use change. We used a global map of biomass carbon stored in above- and below-ground living vegetation (Ruesch \& Gibbs, 2008), restricted to natural land cover (i.e. urban and agricultural areas were excluded; EC-JRC, 2006). By overlaying protected areas with the carbon layer we calculated the carbon storage in the global protected area network.

\section{Carbon storage in important unprotected sites}

We used the following procedure to estimate the carbon storage in unprotected sites that are important for biodiversity. Firstly, carbon storage in unprotected IBAs was estimated based on the unprotected area of IBAs multiplied by the mean carbon density for all IBAs. Secondly, we extrapolated carbon storage to unprotected KBAs by assuming that KBAs have the same carbon density as IBAs. Thirdly, we extrapolated to include those countries not having IBAs (excluding Antarctica) by assuming that unprotected IBAs/KBAs have the same carbon density as protected areas in these countries.

\section{Additional area needed for carbon storage in important unprotected sites}

We estimated how much additional area would be needed to reach arbitrarily chosen global targets of securing 75 and $90 \%$ of total biomass carbon in natural habitats by selecting the areas with the highest density of carbon until the targets were met. To do this we excluded the current protected areas and important sites for biodiversity (IBAs and KBAs) from the global biomass layer and selected the sites with highest carbon storage from the carbon layer until the targets were met.

\section{Results}

Our methodology reveals that the global network of protected areas protects a total of c. 19 million $\mathrm{km}^{2}$, equivalent to $12.9 \%$ of land (Fig. 1). We estimate that the total area of important but unprotected sites for biodiversity is $4.1 \%$ of land; i.e. c. 5.9 million $\mathrm{km}^{2}(3.3 \% \times 1 / 0.8=4.1 \%$; Fig. 1). By overlaying the global network of protected areas with global data on carbon in above- and below-ground living vegetation, we estimate that the existing global 


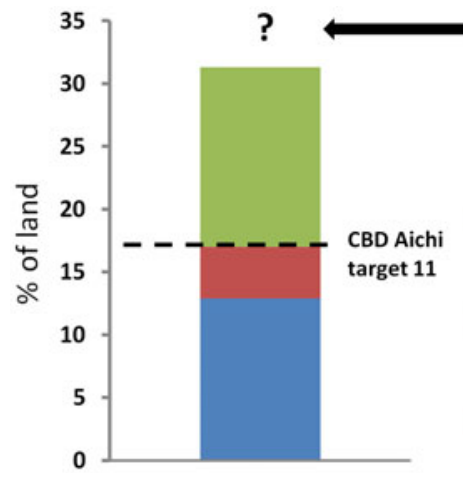

Unprotected important sites for other ecosystem services? Data are not available to provide estimates for area needed to maintain healthy ecosystems to ensure supplies of wide range of ecosystem services such as clean freshwater, crop pollination, coastal protection, and others.

C. 7-14\% Unprotected important sites for carbon storage To ensure storage of $90 \%$ of biomass carbon in natural habitats c. $14 \%$ extra land is needed.

- C. $4.1 \%$ Unprotected important sites for biodiversity A very conservative estimate based on assessments for better-known taxonomic groups only.

C. $12.9 \%$ Current coverage by protected areas
FIG. 1 Comparison of CBD Aichi Target 11 (global protected area target of $17 \%$ of land by 2020) with the current global coverage of protected areas, important unprotected areas for biodiversity, and important unprotected areas for carbon storage. network of protected areas stores c. $25 \%$ of the global biomass carbon in natural habitats; i.e. c. 103 petagrams of carbon $(\mathrm{Pg} \mathrm{C})$. We estimate the carbon storage in the important unprotected sites for biodiversity (4.1\% of extra land) to be c. $22 \mathrm{Pg} \mathrm{C}$, which is c. $5 \%$ of the global total. Thus, the current protected areas (12.9\% of land) and the important unprotected sites for biodiversity (4.1\% of extra land) are estimated to store c. $125 \mathrm{Pg} \mathrm{C}$ (c. $30 \%$ of the global total). We found that an additional c. 11 million $\mathrm{km}^{2}$ (7.5\% of land) would be needed to reach a target of securing $75 \%$ of total biomass carbon in natural habitats, and an additional c. 21 million $\mathrm{km}^{2}(14.3 \%)$ to reach a target of 90\% (Fig. 1).

\section{Discussion}

We found that closing the critical gap in the existing global network of protected areas by protecting the important sites for biodiversity would alone bring the global protected area coverage to $c .17 \%$, equivalent to the current CBD protected area target for land by 2020. This is a conservative estimate because, where they already exist, priority sites are only identified for known species in select well-known taxa, including mammals, amphibians, birds, subsets of reptiles, plants, freshwater fish, and insects such as Odonata and butterflies. Thus, this estimate does not necessarily capture the vast majority of biodiversity for which there is poor knowledge of distributions, such as many invertebrates. Also, our estimate does not take into account potential area needs for biodiversity to adapt to climate change by shifting species distributions or other impacts (Hole et al., 2009; Araujo et al., 2011). In addition, our estimate assumes that future increases in area protected will be focused on the most important sites for biodiversity, which is often not the case (Butchart et al., 2012).

Aichi Target 11 focuses on 'areas of particular importance for biodiversity and ecosystem services'. Conservation efforts in the important unprotected areas for biodiversity will not only help protect biodiversity but also ensure provision of a wide range of ecosystem services. Globally, a disproportionate share of ecosystem services are generated in the areas most important for biodiversity conservation (Larsen et al., 2012; Turner et al., 2012). Nonetheless, not all important sites for delivery of ecosystem services will be covered by sites of highest importance for biodiversity (Turner et al., 2007; Naidoo et al., 2008; Egoh et al., 2009). Thus, the estimate of an additional $4.1 \%$ of land area for conservation of biodiversity does not yet explicitly address human dependence on these ecosystem services.

What would constitute a suitable level of carbon storage in natural habitats remains an open question. If we arbitrarily assume we need to protect $75-90 \%$ of the unprotected carbon stock, this would require protection of an additional $7-14 \%$ of land area if the areas with the highest carbon density were selected. Although these are crude estimates they nevertheless illustrate the magnitude of the additional area required to attain an ambitious target of carbon storage in natural terrestrial habitats. The conversion of unprotected ecosystems with high carbon storage would exacerbate $\mathrm{CO}_{2}$ emissions, and therefore efforts to mitigate climate change would need to ensure higher carbon storage. For example, adding the extra $14.3 \%$ of land required to reach the target of storing $90 \%$ of biomass carbon in natural habitats would secure c. $246 \mathrm{Pg} \mathrm{C}$. In comparison, $\mathrm{CO}_{2}$ emissions from fossil fuel in 2009 constituted $30.8 \mathrm{Pg} \mathrm{CO}_{2}$ (the equivalent of $8.4 \pm \mathrm{SE} 0.5 \mathrm{Pg} \mathrm{C}$; Friedlingstein et al., 2010). If all the carbon stored in the extra c. $14.3 \%$ of important areas for carbon were emitted as a result of land-use change, the resulting $\mathrm{CO}_{2}$ emissions would be c. 29 times the global fossil fuel $\mathrm{CO}_{2}$ emissions in $2009(246 / 8.4=29)$. We focused on living biomass carbon (and omitted soil organic carbon and dead biomass carbon) as there is much more uncertainty in the change of these carbon pools following land-use change. In general a smaller portion of soil carbon and dead biomass carbon is emitted following land-use change such as deforestation (Brown, 2002), but degradation of peat can release considerable amounts of $\mathrm{CO}_{2}$ (van der Werf et al., 2009). Although other data and methods may reveal other important areas for carbon storage, the magnitude of the extra area needed to reach high targets for carbon storage seems less likely to change.

Thus, our estimate illustrates that the CBD target of $17 \%$ protected area coverage by 2020 will fall short of the substantial potential of protected areas to mitigate climate 
change. Our estimate omits other ecosystem services, which are not always spatially aligned (Larsen et al., 2011). Although many of these important areas for securing carbon lie in ecosystems such as tropical rainforests that harbour substantial biodiversity and also provide other ecosystem services, the overlap with areas important for other ecosystem services will be far from complete. The need for multiple ecosystem services will be more spatially distributed than carbon storage. Whereas stores of carbon are in some sense globally exchangeable, other services depend on the proximity of people who depend upon them, and thus their protection must be more equitably distributed. Thus, ours is probably a conservative estimate, best thought of as a minimum bound to the total area needed to safeguard biodiversity and essential ecosystem services. How much additional land needs protection to also maintain healthy ecosystems important for supplies of clean freshwater, crop pollination, mitigation of disasters, and human adaptation to climate change, among others? For example, natural ecosystems can play a key role in helping people adapt to climate change (Turner et al., 2009). So-called ecosystem-based adaptation approaches recognize the capacity of nature to buffer human communities against the adverse impacts of climate change through the sustainable delivery of 'adaptation services' (Jones et al., 2012). Mangrove forests and coastal marshes, for example, can help reduce disaster risk as they are natural buffers that provide protection against erosion and wave damage along exposed coastlines.

Although our preliminary estimates must be refined as data improve, they nevertheless illustrate that protection of $17 \%$ of land will almost certainly be insufficient to halt loss of biodiversity and essential ecosystem services even if the most important areas are protected. The CBD target of at least $17 \%$ protected area coverage by 2020 should be seen as an incremental target towards a higher long-term global target, perhaps up to $50 \%$ or more given the variety and importance of ecosystem services to societies worldwide. However, although protected areas are an essential tool they are not the only means to halt biodiversity loss and secure ecosystem services. Given the increasing pressure from many competing land uses (e.g. agricultural expansion) it may be politically infeasible to dedicate a much higher proportion of land for nature. Human population growth and rising consumption are increasing the pressure to convert intact ecosystems into other forms of land use. Projections for 2050 are that the global human population will increase beyond 9 billion, world GDP will quadruple, and the global need for energy and water will increase by 80 and $55 \%$, respectively (OECD, 2012). Unless efforts are made to protect a higher proportion of natural ecosystems from conversion and degradation in the most important places, nature's ability to support biodiversity and sustain human well-being will be compromised to the detriment of all species. To prevent us from transgressing important planetary boundaries we need global targets based on scientific understanding of how existing natural ecosystems support biodiversity and sustain the delivery of critical ecosystem services.

\section{Acknowledgements}

We thank BirdLife International for data on Important Bird Areas, and Lina Barrera and Conrad Savy for helpful discussions. All authors are grateful for funding from the Gordon and Betty Moore Foundation.

\section{References}

Araujo, M.B., Alagador, D., Cabeza, M., Nogues-Bravo, D. \& Thuiller, W. (2011) Climate change threatens European conservation areas. Ecology Letters, 14, 484-492.

Balmford, A., Bruner, A., Cooper, P., Costanza, R., Farber, S., GreEN, R.E. et al. (2002) Economic reasons for conserving wild nature. Science, 297, 950-953.

Barnosky, A.D., Hadly, E.A., Bascompte, J., Berlow, E.L., Brown, J.H., Fortelius, M. et al. (2012) Approaching a state shift in Earth's biosphere. Nature, 486, 52-58.

Birdife International (2011) State of the World's Birds. BirdLife International, Cambridge, UK.

Brown, S. (2002) Measuring carbon in forests: current status and future challenges. Environmental Pollution, 116, 363-372.

Butchart, S.H.M., Scharlemann, J.P.W., Evans, M.I., Quader, S., Arico, S., Arinaitwe, J. et al. (2012) Protecting important sites for biodiversity contributes to meeting global conservation targets. PLOS ONE, 7(3), e32529.

Butchart, S.H.M., Walpole, M., Collen, B., van Strien, A., Scharlemann, J.P.W., Almond, R.E.A. et al. (2010) Global biodiversity: indicators of recent declines. Science, 328, 1164-1168.

CBD (Convention on Biological Diversity) (2010a) Global Biodiversity Outlook 3. Secretariat of the Convention on Biological Diversity, Montreal, Canada.

CBD (Convention on Biological Diversity) (2010b) COP 10 Decision X/2. The Strategic Plan for Biodiversity 2011-2020 and the Aichi Biodiversity Targets. Http://www.cbd.int/decision/cop/default. shtml?id=12268 [accessed 12 March 2014].

CBD (Convention on Biological Diversity) (2012) 2010 Biodiversity Target. Http://www.cbd.int/2010-target [accessed 9 October 2012].

Dudley, N. (2008) Guidelines for Applying Protected Area Management Categories. IUCN, Gland, Switzerland.

Dudley, N. \& Stolton, S. (2003) Running Pure: the Importance of Forest Protected Areas to Drinking Water. WWF/World Bank Alliance for Forest Conservation and Sustainable Use, Gland, Switzerland.

EC-JRC (European Commission Joint Research Centre) (2006) Global Land Cover 2000 Database. European Commission Joint Research Centre, Ispra, Italy.

Egoh, B., Reyers, B., Rouget, M., Bode, M. \& Richardson, D.M. (2009) Spatial congruence between biodiversity and ecosystem services in South Africa. Biological Conservation, 142, 553-562.

Eken, G., Bennun, L., Brooks, T.M., Darwall, W., Fishpool, L.D.C., Foster, M. et al. (2004) Key biodiversity areas as site conservation targets. BioScience, 54, 1110-1118. 
Friedlingstein, P., Houghton, R.A., Marland, G., Hackler, J., Boden, T.A., Conway, T.J. et al. (2010) Update on $\mathrm{CO}_{2}$ emissions. Nature Geoscience, 3, 811-812.

Hole, D.G., Willis, S.G., Pain, D.J., Fishpool, L.D., Butchart, S.H.M., Collingham, Y.C. et al. (2009) Projected impacts of climate change on a continent-wide protected area network. Ecology Letters, 12, 420-431.

IUCN \& UNEP-WCMC (2011) The World Database on Protected Areas (WDPA). UNEP-WCMC, Cambridge, UK.

Jones, H.P., Hole, D.G. \& Zavaleta, E.S. (2012) Harnessing nature to help people adapt to climate change. Nature Climate Change, 2, 504-509.

Kremen, C. \& Ostfeld, R.S. (2005) A call to ecologists: measuring, analyzing, and managing ecosystem services. Frontiers in Ecology and the Environment, 3, 540-548.

Langhammer, P.F., Bakarr, M.I., Bennun, L.A., Brooks, T.M., Clay, R.P., DarWall, W. et al. (2007) Identification and Gap Analysis of Key Biodiversity Areas: Targets for Comprehensive Protected Area Systems. IUCN, Gland, Switzerland.

Larsen, F.W., Londono-Murcia, M.C. \& Turner, W.R. (2011) Global priorities for conservation of threatened species, carbon storage, and freshwater services: scope for synergy? Conservation Letters, 4, 355-363.

Larsen, F.W., Turner, W.R. \& Brooks, T.M. (2012) Conserving critical sites for biodiversity provides disproportionate benefits to people. PLoS ONE, 7, e36971.

Lovejoy, T.E. (2006) Protected areas: a prism for a changing world. Trends in Ecology \& Evolution, 21, 329-333.

McCarthy, D.P., Donald, P.F., Scharlemann, J.P.W., Buchanan, G.M., Balmford, A., Green, J.M.H. et al. (2012) Financial costs of meeting global biodiversity conservation targets: current spending and unmet needs. Science, 338, 946-949.

McKinsey \& Company (2009) Pathways to a Low-Carbon Economy: Version 2 of the Global Greenhouse Gas Abatement Cost Curve. McKinsey \& Company, New York, USA.

Millennium Ecosystem Assessment (2005) Ecosystems and Human Well-Being. Island Press, Washington, DC, USA.

Mittermeier, R.A., Robles Gil, P., Hoffmann, M., Pilgrim, J., Brooks, T.M., Mittermeier, C.G. et al. (2004) Hotspots Revisited: Earth's Biologically Richest and Most Endangered Ecoregions. Cemex, Mexico City, Mexico.

Mittermeier, R.A., Turner, W.R., Larsen, F.W., Brooks, T.M. \& GAsCon, C. (2011) Global biodiversity conservation: the critical role of hotspots. In Biodiversity Hotspots (eds F.E. Zachos \& J.C. Habel), pp. 3-22. Springer, Berlin, Germany.

Mora, C., Tittensor, D.P., Adl, S., Simpson, A.G.B. \& Worm, B. (2011) How many species are there on Earth and in the ocean? PLoS Biology, 9, e1001127.

Myers, N., Mittermeier, R.A., Mittermeier, C.G., Da FonsecA, G.A.B. \& Kent, J. (2000) Biodiversity hotspots for conservation priorities. Nature, 403, 853-858.

Naidoo, R., Balmford, A., Costanza, R., Fisher, B., Green, R.E., Lehner, B. et al. (2008) Global mapping of ecosystem services and conservation priorities. Proceedings of the National Academy of Sciences of the United States of America, 105, 9495-9500.

OECD (The Organisation for Economic Cooperation and Development) (2012) OECD Environmental Outlook to 2050. OECD Publishing, Paris, France.

Ricketts, T.H., Dinerstein, E., Boucher, T., Brooks, T.M., Butchart, S.H.M., Hoffmann, M. et al. (2005) Pinpointing and preventing imminent extinctions. Proceedings of the National Academy of Sciences of the United States of America, 102, $18497-18501$
Ricketts, T.H., Soares-Filho, B., da Fonseca, G.A.B., Nepstad, D., Pfaff, A., Petsonk, A. et al. (2010) Indigenous lands, protected areas, and slowing climate change. PLoS Biology, 8(3), e1000331.

Rockström, J., Steffen, W., Noone, K., Persson, A., Chapin, F.S., Lambin, E. et al. (2009a) Planetary boundaries: exploring the safe operating space for humanity. Ecology and Society, 14, 32.

Rockström, J., Steffen, W., Noone, K., Persson, A., Chapin, F.S., LAMBin, E.F. et al. (2009b) A safe operating space for humanity. Nature, 461, 472-475.

Ruesch, A.S. \& Gibis, H.K. (2008) New IPCC Tier-1 Global Biomass Carbon Map for the Year 200o. Oak Ridge National Laboratory, Oak Ridge, USA.

Sachs, J.D., Baillie, J.E.M., Sutherland, W.J., Armsworth, P.R., Ash, N., Beddington, J. et al. (2009) Biodiversity conservation and the Millennium Development Goals. Science, 325, 1502-1503.

Scharlemann, J.P.W., Kapos, V., Campbell, A., Lysenko, I., Burgess, N.D., Hansen, M.C. et al. (2010) Securing tropical forest carbon: the contribution of protected areas to REDD. Oryx, $44,352-357$.

Stuart, S.N., Wilson, E.O., McNeely, J.A., Mittermeier, R.A. \& Rodriguez, J.P. (2010) The barometer of life. Science, 328, 177.

TEEB (The Economics of Ecosystems and Biodiversity) (2010) The Economics of Ecosystems and Biodiversity: Mainstreaming the Economics of Nature: A Synthesis of the Approach, Conclusions and Recommendations of TEEB. Http://www. unep.org/pdf/LinkClick.pdf [accessed 11 March 2014].

The Nature Conservancy (2012) Aichi Target 11-Reshaping the Global Agenda for MPAs. Http://www.nature.org/newsfeatures/ pressreleases/tnc-marine-policy-brief-2012.pdf [accessed 6 November 2012].

Toropova, C., Meliane, I., Laffoley, D., Matthews, E. \& Spalding, M. (eds) (2010) Global Ocean Protection: Present Status and Future Possibilities. Http://data.iucn.org/dbtw-wpd/edocs/2010053.pdf [accessed 14 March 2014].

Turner, W.R., Brandon, K., Brooks, T.M., Costanza, R., Da Fonseca, G.A.B. \& Portela, R. (2007) Global conservation of biodiversity and ecosystem services. BioScience, 57, 868-873.

Turner, W.R., Brandon, K., Brooks, T.M., Gascon, C., Gibbs, H.K., LAWrence, K.S. et al. (2012) Global biodiversity conservation and the alleviation of poverty. BioScience, 62, 85-92.

Turner, W.R., Oppenheimer, M. \& Wilcove, D.S. (2009) A force to fight global warming. Nature, 462, 278-279.

UNDP (UN Development Programme) (2011) Human Development Report 2011. Sustainability and Equity: A Better Future for All. UNDP, New York, USA.

UNFCCC (UN Framework Convention on Climate Change) (2010) Cancun Agreements. Http://unfccc.int/meetings/ cancun_nov_2010/items/6005.php [accessed 7 March 2014].

van der Werf, G.R., Morton, D.C., DeFries, R.S., Olivier, J.G.J., Kasibhatla, P.S., JaCKson, R.B. et al. (2009) $\mathrm{CO}_{2}$ emissions from forest loss. Nature Geoscience, 2, 737-738.

\section{Biographical sketches}

FRANK W. LARSEN's interests focus on conservation priorities for biodiversity and ecosystem services and how science can support policy. Will R. TURner focuses on integrating our knowledge of biodiversity, climate change and socio-economics to safeguard nature and support the billions who depend on it. RusSELL A. Mittermeier is a primatologist and his interests cover primates, amphibians, conservation priorities and biodiversity science. 